\title{
SYNERGISTIC EFFECT OF HYPEROXIA AND BIOTRAUMA ON VENTILATOR-INDUCED LUNG INJURY
}

\author{
Mirjana Shosholcheva $^{1}$, Nikola Jankulovski ${ }^{2}$, Andrijan Kartalov $^{3}$, Biljana Kuzmanovska ${ }^{3}$, Daniela Miladinova ${ }^{4}$ \\ ${ }^{1}$ University Clinic of Surgery "Ss. Naum Ohridski”, Medical Faculty, "Ss. Cyril and Methodius” University, Macedonia \\ ${ }^{2}$ University Clinic for Abdominal Surgery, Medical Faculty, "Ss. Cyril and Methodius" University, Macedonia \\ ${ }^{3}$ Clinic for Anesthesiology, Reanimatology and Intensive Care Unit, Medical Faculty, "Ss. Cyril and Methodius" University, \\ Macedonia \\ ${ }^{4}$ Institute of Pathophysiology and Nuclear Medicine, Medical Faculty, "Ss. Cyril and Methodius" University, Macedonia
}

Corresponding Authors: Mirjana Shosholcheva, Professor of Anesthesia and Intensive Care, Department of Anesthesia and Intensive Care, University Clinic of Surgery "Ss. Naum Ohridski", "Ss Cyril and Methodius" University, Medical Faculty, Macedonia, Tel: +38975219488 Email: sosolceva@hotmail.com

\begin{abstract}
Patients undergoing mechanical ventilation in intensive care units (ICUs) may develop ventilator-induced lung injury (VILI). Beside the high tidal volume (Vt) and plateau pressure (Pplat), hyperoxia is supposed to precipitate lung injury. Oxygen toxicity is presumed to occur at levels of fraction of inspired oxygen $\left(\mathrm{FiO}_{2}\right)$ exceeding 0.40 . The exposure time to hyperoxia is certainly very important and patients who spend extended time on mechanical ventilation (MV) are probably more exposed to severe hyperoxic acute lung injury (HALI). Together, hyperoxia and biotrauma (release of cytokines) have a synergistic effect and can induce VILI. In the clinical practice, the reduction of $\mathrm{FiO}_{2}$ to safe levels through the appropriate use of the positive end expiratory pressure (PEEP) and the alignment of mean airway pressure is an appropriate goal. The strategy for lung protective ventilation must include setting up $\mathrm{FiO}_{2}$ to a safe level that is accomplished by using $\mathrm{PaO}_{2} / \mathrm{FiO}_{2}$ ratio with a lower limit of $\mathrm{FiO}_{2}$ to achieve acceptable levels of $\mathrm{PaO}_{2}$, which will be safe for the patient without local (lungs) or systemic inflammatory response. The protocol from the ARDS-net study is used for ventilator setup and adjustment. Cytokines (IL-1, IL-6, TNF $\alpha$ and MIP-2) that are involved in the inflammatory response are determined in order to help the therapeutic approach in counteracting HALI. Computed tomography findings reflect the pathological phases of the diffuse alveolar damage. At least preferably the lowest level of $\mathrm{FiO}_{2}$ should be used in order to provide full lung protection against the damage induced by MV.
\end{abstract}

Keywords: hyperoxia, ventilator-induced lung injury, cytokines, lung-protective ventilation strategies

\section{INTRODUCTION}

Providing effective life-support with minimized risk and optimized comfort in patients with respiratory failure are still the principal objectives of mechanical ventilation (MV) [1]. Despite its life saving effects, MV might have adverse effects: ventilator-associated pneumonia, impaired cardiac performance, and difficulties with sedation and paralysis. The mechanical ventilation may also lead to serious damage in both healthy and diseased lungs; a process called ventilator-induced lung injury (VILI).
In the past the inadequate ventilation strategy was considered to be responsible for the onset of VILI, that is, histopatologically identical with the acute lung injury (ALI). However, recently, more detailed factors for development of VILI have emerged: loading of alveolocapillary membrane, duration of exposure to MV, intensity of the exposure (tidal volume; $\mathrm{Vt}$ ), end-expiratory pulmonary volume, magnitude of the available "baby lung" heterogeneity (which includes atelectasis, consolidation and edema) and hyperoxia. Endotoxin, vascular pressures and fluid/ transfusions are additional factors leading to VILI 
$[2,3]$. High Vt and high plateau pressure (Plat) can give excessive distension, or "stretch," of the aerated lungs, thus resulting in volutrauma and barotrauma. Besides the volutrauma and barotrauma, atelectrauma is another important causative factor leading to VILI. Ventilator-induced lung injury arises not only from repeated application of high mechanical forces that tear fragile tissue directly, but also from initiation of signaling that culminates in inflammatory changes [4]. The term "biotrauma" denotes release of cytokines (mediators) secondary to epithelial injury caused by barotrauma or volutrauma [5]. Ventilator-induced lung injury greatly assists patients with the most severe form of lung injury, acute respiratory distress syndrome (ARDS) [6].

A question arises why hyperoxia, especially if it lasts long, is not being considered as a risk factor for the development of VILI along with the other factors. Oxygen therapy has been used in the care of critically ill patients since early years of the last century. However, from the beginnings of the 1970s an increasing understanding emerged that oxygen therapy can cause pulmonary toxicity [7]. Hyperoxia is detrimental for mechanically ventilated patients and even fraction of inspired oxygen $\left(\mathrm{FiO}_{2}\right)$ levels of 0.40 and lower can provoke pulmonary toxicity, thus leading to VILI. The exposure time to hyperoxia is certainly very important and patients who spend extended time on MV are probably more exposed to severe hyperoxic acute lung injury (HALI) [8].

Hyperoxia is supposed to precipitate lung injury through the production of reactive oxygen intermediates [9]. Hyperoxia provokes cytokine release, which is involved in the inflammatory response. Endothelial and epithelial cells injury, increased pulmonary capillary permeability and a marked increase in the inflammatory cells are the main manifestations of HALI [10]. Microscopically the prominent findings are: hyaline membrane formation in alveoli, alveolar septal edema and fibrosis, and diffuse hyperplasia of the alveolar lining layer with formation of a cuboidal epithelial lining [7]. The combination of high Vt and hyperoxia causes significantly greater reductions in the lung compliance, increased alveolar-capillary membrane permeability, gives more severe pulmonary surfactant dysfunction [11], and increases expression of pro-inflammatory mediators $[12,13]$. These notions have been confirmed in a several number of studies, which showed that cyclic opening and collapse of the alveoli even at low inspiratory pressures and low inspiratory volumes increased stretch and shear forces resulting in lung injury and surfactant dysfunction $[14,15]$. Inflammation and more specifically, cytokines such as tumor necrosis factor - alpha (TNF $\alpha$ ) and interleukin (IL)-I are thought to decrease surfactant components either directly [14-17] or indirectly by inducing alveolar leakage of proteins that subsequently inhibit surfactant function [14-18]. Cytokines play the most important role in inflammation. They are low molecular weight soluble proteins that transmit signals between the cells involved in the inflammatory response [19]. Cytokines are produced by bronchial, bronchiolar, and alveolar epithelial cells but also by alveolar macrophages and neutrophils [20]. In almost all studies in-vitro, ex-vivo and in-vivo models, using different species and applying various techniques, hyperoxia induced elevation of cytokines. Furthermore, in almost all studies, cyclic overstretch has increased alveolar levels of IL-8 or its rodent equivalent macrophages inflammatory protein (MIP)-2. MIP-2 is the most potent leukocyte chemoattractant and its role in the pathogenesis of VILI is very important $[21,22]$. Other proinflammatory cytokines such as IL-1and IL-6 were elevated in a large number of studies.

\section{FIO, LEVELS: DIFFERENT ATTITUDES, BELIEFS AND PRACTICES}

Considerable variations exist in the attitudes, beliefs, and stated practices relating to the management of oxygen therapy in the ICUs patients. A Canadian questionnaire study has shown that most respondents believed that the levels of $\mathrm{FiO}_{2}$ up to 0.40 are not harmful and this is the ideal value when partial pressure of oxygen in arterial blood $\left(\mathrm{PaO}_{2}\right)$ permits this [23]. Another newer study from the Netherlands investigated the beliefs and actual clinical practice regarding the oxygen therapy in critically ill patients where the majority of ICUs clinicians acknowledged the potential adverse effects of prolonged exposure to hyperoxia and reported a low tolerance for high oxygen levels, in actual clinical practice; a large proportion of their ICUs patients was exposed to higher arterial oxygen levels [24, 25].

However, there is evidence of poor outcomes after hyperoxia in a number of patients mechanically ventilated, but in most cases this did not lead to adjustment of ventilator settings [10]. All the doctors in ICUs have their "own" mode of setting the ventilator, but almost always patients on MV are exposed to greater than normal concentration of oxygen. Additionally, in some patients it is not possible to develop a ventilation strategy that is non-injurious in all lung regions and hence the problem becomes more complex. 
Clinical practice shows that whenever we have a low $\mathrm{PaO}_{2}$, the first step we undertake is to set the $\mathrm{FiO}_{2}$ on a higher level. It is well-known that this is not the right way to increase $\mathrm{PaO}_{2}$, but in spite of that, we are used. In this protocol, higher PEEP with lower $\mathrm{FiO}_{2}$ is used. The higher PEEP levels are set and adjusted according to each patient's arterial-oxygenation response to the $\mathrm{PEEP} / \mathrm{FiO}_{2}$ settings [29]. (Table 1).

Table 1. Higher PEEP levels with Lower $\mathrm{FiO}_{2}$

\begin{tabular}{|c|c|c|c|c|c|c|c|c|}
\hline $\mathbf{F i O}_{2}$ & 03 & 0.3 & 0.3 & 0.3 & 0.3 & 0.4 & 0.4 & 0.5 \\
\hline PEEP & 5 & 8 & 10 & 12 & 14 & 14 & 16 & 16 \\
\hline
\end{tabular}

always repeat it and moreover, for a longer period of time. $\mathrm{FiO}_{2}$ setting value is usually about 0.4 , but even oxygen toxicity is presumed to occur at levels of $\mathrm{FiO}_{2}$ exceeding 0.40 , there are no studies which have examined the effect of $\mathrm{FiO}_{2}$ value less than 0.4 on the lungs. It would be of great benefit to perform studies that will apply protective ventilation strategies with different levels of $\mathrm{FiO}_{2}$, but especially with $\mathrm{FiO}_{2}$ under 0.4.

\section{RATIONALE STRATEGY FOR LUNG PROTECTIVE VENTILATION}

In order to achieve lower $\mathrm{FiO}_{2}$ level than 0.4, which is safe for the patient, it is necessary to decrease $\mathrm{FiO}_{2}$ to safe levels through appropriate use of the positive end expiratory pressure (PEEP) and the alignment of the mean airway pressure. An acceptable level of $\mathrm{PaO}_{2} / \mathrm{FiO}_{2}$ ratio with a lower limit of $\mathrm{FiO}_{2}$ must be accomplished. This way, adequate tissue oxygenation with $\mathrm{FiO}_{2}$ levels less than 0.40 will be achieved.

The modes of mechanical ventilation are adjusted according to the protocol of the ARDS-net study (based on open lung concept) [26]. The ARDS network study gives a golden protocol for lung protective ventilation. Ventilation protective strategies are used routinely without fulfilling the criteria for ALI/ ARDS [27]. The ARDS network study demonstrated a compelling survival advantages when using low tidal volumes rather than conventional MV with high tidal volumes in patients with ALI or ARDS [28].

According to the protocol, the ventilator set up and adjustment is as follows: MV is adjusted to the body mass, with an initial $\mathrm{Vt}$ of $8 \mathrm{ml} / \mathrm{kg} / \mathrm{bw}$ and reducing $\mathrm{Vt}$ by $1 \mathrm{ml} / \mathrm{kg} / \mathrm{bw}$ at intervals not more than 2 hours, until reaching the $\mathrm{Vt}$ of $6 \mathrm{ml} / \mathrm{kg} / \mathrm{bw}$, with plateau airway pressure (Pplat) not exceeding $30 \mathrm{cmH}_{2} \mathrm{O}$. Furthermore, $\mathrm{PaO}_{2}$ between $55-80 \mathrm{mmHg}$ or saturation of the arterial blood oxygen $\left(\mathrm{SaO}_{2} \%\right)$ 88-95\% and minute ventilation of 6-35 respirations per minute adjusted to achieve arterial $\mathrm{pH} \geq 7.30$ if possible and inspiration:expiration time 1:1-1:3 are accepted values. A minimum PEEP of $5 \mathrm{cmH}_{2} \mathrm{O}$, and incremental PEEP/ $\mathrm{FiO}_{2}$ combinations
From the National Heart, Lung, and Blood Institute ARDS Clinical Trials Network. N Engl Med 2004; 351:327 [29].

However, it is still unclear which is the optimal PEEP that has to be used to avoid overdistension of the alveoli and de-recruitment, and to minimize VILI [30,31].

Regarding Pplat, to reach Pplat $\leq 30 \mathrm{~cm} \mathrm{H}_{2} \mathrm{O}$ after each change in PEEP or VT, Pplat ( 0.5 second inspiratory pause) has to be checked [27].

Recruitment maneuvers are performed to maximize the amount of open lung while avoiding the high tissue stresses that lead to VILI. Extended sigh recruitment maneuver has better improvement of oxygenation in arterial blood than CPAP recruitment maneuver [32,33].

Additionally, bedside the monitoring, the following is necessary: heart rate, electrocardiogram, non-invasive mean arterial pressure, respiratory rate, oxygen saturation, $\mathrm{FiO}_{2}$, arterial blood gas analysis (monitored half an hour after every MV adjustment), serial chest X-ray and chest/lung computed tomography that reflect the pathologic phases of diffuse alveolar damage [34]. Immunological analyses of cytokines: IL-1, IL-6, TNF $\boldsymbol{\alpha}$ and MIP-2 also have to be made.

Precise control of the arterial oxygenation to minimize the possible harms of hypoxemia is an issue that is extremely important, as at present there is no direct evidence to support the implementation of permissive hypoxemia [35].

The effects of open lung ventilation with reduced $\mathrm{FiO}_{2}$ of 0.4 will prevent not only local, but systemic inflammatory response as well. Furthermore, the effects of setting $\mathrm{FiO}_{2}$ values at 0.3 will be more reliable. The effects will of course depend on the condition of the lungs (healthy or diseased prior to MV). Evidence for oxygen use in different medical conditions where efficacy and/or safety are uncertain relies on anecdotal experiences, case reports, or small, underpowered studies and require large randomized controlled clinical trials [36].

The rationale of this approach will determine the exact $\mathrm{FiO}_{2}$ level necessary for safe $\mathrm{MV}$. 


\section{CONCLUSION}

Patients undergoing MV might develop VILI. Hyperoxia is detrimental for mechanically ventilated patients and may lead to VILI. VILI can appear as a result of too much $\mathrm{O}_{2}$, large tidal volumes, high inspiratory pressures, cyclic opening/closing of the alveoli and all these lead to release of cytokines. The release of cytokines leads to biochemical injury, which is the concept of biotrauma. The lungs are metabolically active organs composed of epithelium and endothelium that create many substances. They are a door to many pathogens and may be source of systematic inflammation. Alveolar epithelial cells are important for maintaining alveolocapillary barrier and can act as immune effector cells in response to exogenous stimuli (MV). The mechanical ventilation together with hyperoxia are responsible for the cytokine increase and may play a role in initiating a possible systematic inflammatory response. Together, hyperoxia and biotrauma have a synergistic effect and can induce VILI.

The prevention of VILI means also prevention of HALI. Lung-protective ventilation strategies provide avoidance of cyclic opening and closing of alveoli, limitation of inspiratory pressures and volumes, appropriate level of the end-expiratory pressure and together with the appropriate (preferable lowest) level of $\mathrm{FiO}_{2}$ can give full lung protection against the damage induced by mechanical ventilation.

\section{REFERENCES}

1. Marini J J. Mechanical ventilation: past lessons and the near future. Critical Care. 2013; 17(Suppl 1):S1 http://ccforum.com/content/17/S1/S1

2. Luciano Gattinoni L, Marini J J, Pesenti A et al. The "baby lung" became an adult. Intensive Care Med. 2016; 42:663-673

3. Itagaki T, Nakano Y, Okuda $\mathrm{N}$ et al. Hyperoxemia in Mechanically Ventilated, Critically Ill Subjects: Incidence and Related Factors. Respir Care. 2015; 60(3):335-340

4. Dreyfuss D, Saumon G. Ventilator-induced lung injury: lessons from experimental studies. Am J Respir Crit Care Med. 1998; 157:294-323

5. Curley GF, Laffey JG, Zhang H et al. Biotrauma and Ventilator Induced Lung Injury: Clinical implications. Chest. 2016; pii: S00123692(16)52763-9.

6. Pinhu L, Whitehead T, Evans T et al. Ventilator associated lung injury. Lancet. 2003; 361:332-340
7. Jackson RM. Pulmonary oxygen toxicity. Chest. 1985; 88:900-905

8. Richard H, Kallet R H, Matthay MA. Hyperoxic Acute Lung Injury. Respiratory Care. 2013; 58 (1): 123-141

9. Altemeier WA, Scott SE. Hyperoxia in the intensive care unit: why more is not always better. Curr Opin Crit Care. 2007; 13:73-78

10. Graaff AE, Dongelmans DA, Binnekade JM et al. Clinicians' response to hyperoxia in ventilated patients in a Dutch ICU depends on the level of FiO2. Intensive Care Med. 2011; 37:46-51

11. Bailey TC, Martin EL, Xiao L et al. High oxygen concentrations predisposed mouse lungs to the deleterious effects of high stretch ventilation. J Appl Physiol. 2003; 94(3):975-982.

12. Kallet R H, Matthay M A. Hyperoxic Acute Lung Injury. Respir Care. 2013;58(1): 123-141.

13. Li L-F, Liao S-K, Lee C-H et al. Hyperoxia increases ventilator-induced lung injury by mitogen-activated protein kinases: a prospective, controlled animal experiment. Crit Care. 2007; 11(1):R25.

14. Halbertsma FJJ, Vanecker M, Scheffer GJ et al. Cytokines and biotrauma in ventilator-induced lung injury: a critical review of the literature. The Netherlands Journal of Medicine. 2005; 63:382-392

15. Dreyfuss D, Saumon G. Role of tidal volume, FRC, and end-inspiratory volume in the development of pulmonary edema following mechanical ventilation. Am Rev Respir Dis. 1993;148(5):1194-203

16. Mead J, Takishima T, Leith D. Stress distribution in lungs: a model of pulmonary elasticity. J Appl Physiol. 1970; 28(5):596-608.

17. Colmenero-Ruiz M, Fernandez-Mondejar E, Fernandez-Sacristan MA et al. PEEP and low tidal volume ventilation reduce lung water in porcine pulmonary edema. Am J Respir Crit Care Med. 1997; 155(3):964-70

18. Montgomery AB, Stager MA, Carrico CJ et al. Causes of mortality in patients with the adult respiratory distress syndrome. Am Rev Respir Dis. 1985;132(3):485-9.

19. Strieter RM, Belperio JA, Keane MP. Cytokines in innate host defense in the lung. J Clin Invest. 2002;109(6):699-705.

20. Pugin J, Dunn I, Jolliet P et al. Activation of human macrophages by mechanical ventilation in vitro. Am J Physiol. 1998; 275(6 Pt 1):L1040-50. 
21. Kawano T, Mori S, Cybulsky M et al. Effect of granulocyte depletion in a ventilated surfactant-depleted lung. J Appl Physiol. 1987;62(1):27-33.

22. Eyal FG, Hamm CR, Coker-Flowers P et al. The neutralization of alveolar macrophages reduces barotrauma-induced lung injury. FASEB J. 2002;16:A410.

23. Mao C, Wong DT, Slutsky AS et al. A quantitative assessment of how Canadian intensivists believe they utilize oxygen in the intensive care unit. Crit Care Med.1999; 27:2806-2811

24. Helmerhorst HJ, Schultz MJ, van der Voort PH et al. Self-reported attitudes versus actual practice of oxygen therapy by ICU physicians and nurses. Ann Intensive Care. 2014; 25;4:23

25. Suzuki S, Eastwood GM, Peck L et al. Current oxygen management in mechanically ventilated patients: a prospective observational cohort study. J Crit Care. 2013; 28(5):647-54.

26. Thompson BT, Bernard GR. ARDS Network (NHLBI) Studies - Successes and Challenges in ARDS Clinical Research. Critical Care Clinics. 2011;27(3):459-468.

27. Esteban A, Anzueto A, Frutos F et al. Characterstics and outcomes in adult patients receiving mechanical ventilation; a 28-day international study. JAMA. 2002;287:345-55

28. Acute Respiratory Distress Syndrome Network. Ventilation with lower tidal volumes as compared with traditional tidal volumes for acute lung injury and the acute respiratory distress syndrome. N Engl J Med. 2000; 342:1301-1308
29. Higher versus lower positive end-expiratory pressures in patients with the acute respiratory distrss syndrome. The National, Lung, and Blood Institute ARDS Clinical Trials Network. N Engl J Med 2004; 351: 327-336

30. Gattinoni L, Carlesso E, Cressoni M. Selecting the 'right' positive end-expiratory pressure level. Curr Opin Crit Care. 2015; 21(1):50-7

31. Gattinoni L, Quintel M. How ARDS should be treated. Crit Care. 2016; 20: 86.

32. Hodgson C and Keating JL, HollandAE et al. Recruitment manoeuvers for adults with acute lung injury receiving mechanical ventilatiion. Cochrane database Syst Rev 2009, 15:CD006667

33. Trojik T, Shosholcheva M, Radulovska Chabukovska $\mathrm{J}$ et al. Impact of the e- sigh recruitment manoeuvre on oxygenation and aeration of the lung in patients with ALI/ARDS. Prilozi. 2012;33(2):141-51

34. Ichikado K, Suga M, GushimaY et al. Hyperoxia-induced diffuse alveolar damage in pigs:correlation between thin-section CT and histopathological findings. Radiology 2000; 216 (2):531-538

35. Martin DS and Grocott MP. Oxygen therapy in critical illness: precise control of arterial oxygenation and permissive hypoxemia. Crit Care Med 2013; 41 (2): 423-32

36. Blackeman T. Evidence for oxygen use in the hospitalized patient: is more really the enemy of good? Respir Care 2013; 58 (10): 1679-1693 


\title{
Резиме
}

\section{СИНЕРГЕТСКИ ЕФЕКТ НА ХИПЕРОКСИЈА И БИОТРАУМА НА ВЕНТИЛАТОР-ПРЕДИЗВИКАНА ПОВРЕДА НА БЕЛИТЕ ДРОБОВИ}

\author{
Мирјана Шошолчева ${ }^{1}$, Никола Јанкуловски ${ }^{2}$, Андријан Карталов ${ }^{3}$, \\ Билјана Кузмановска ${ }^{3}$, Даниела Миладинова ${ }^{4}$ \\ ${ }^{1}$ Универзитетска хируршка Клиника „Св Наум Охридски“, Медицински факултет, \\ Универзитет „Св. Кирил и Методиј“, Македонија \\ 2 Универзитетска клиниката за абдоминална хирургија, Медицинскиот факултет, \\ Универзитет „Св. Кирил и Методиј“, Македонија \\ ${ }^{3}$ Клиника за анестезија, реанимација и интензивна нега, Медицинскиот факултет, \\ Универзитет „Св. Кирил и Методиј“, Македонија \\ ${ }^{4}$ Институт за патофизиологија и нуклеарна медицина, Медицинскиот факултет, \\ Универзитет „Св. Кирил и Методиј“, Македонија
}

\section{Апстракт}

Во единиците за интензивна нега (ЕИЛ) пациентите што се поставени на механичка вентилација (MB) можат да развијат вентилатор-предизвикана повреда на белите дробови (ВИЛИ). Покрај големиот дишен волумен $(\mathrm{Vt})$ и плато-притисок (Pplat), и хипероксијата ја влошува белодробната повреда. Се претпоставува дека кислородна токсичност се јавува при вредности на инспираторен кислород $\left(\mathrm{FiO}_{2}\right)$ што се поголеми од 0,40 . Времето на изложеност на хипероксијата е, секако, многу важно и пациентите што поминуваат подолго време на MB се веројатно повеќе изложени на тешка хипероксична акутна белодробна повреда (ХАЛИ). И двете, хипероксијата и биотраумата (ослободување на цитокини) имаат синергистички ефект и можат да предизвикаат ВИЛИ. Во клиничка практика целта е намалување на $\mathrm{FiO}_{2}$ на безбедни вредности со соодветна примена на позитивен притисок на крајот на експириумот (PEЕР) и усогласување на притисокот во дишните патишта. Стратегијата на белодробна протективна вентилација мора да вклучи поставување на $\mathrm{FiO}_{2}$ на безбедно ниво, кое се постигнува со користење на односот $\mathrm{PaO}_{2} /$ $\mathrm{FiO} 2$, со долна граница на $\mathrm{FiO} 2$ за да се постигне прифатливо ниво на $\mathrm{PaO}_{2}$, кое ќе биде безбедно за пациентот без локален (белите дробови) или системски инфламаторен одговор. Протоколот од ARDS-нет студијата се користи за поставување и приспособување на вентилаторот. Се испитуваат цитокините (IL1, IL-6, TNF $\alpha$ и MIP-2) што се вклучени во инфламаторен одговор, со цел да помогнат во терапевтскиот пристап на ХАЛИ. Наодите од компјутеризираната томографија ги одразуваат патолошките фази на дифузното алвеоларно оштетување. Потребно е да се користи најниско ниво на $\mathrm{FiO}_{2}$ за да се обезбеди целосна заштита на белите дробови од оштетување што е предизвикано од МВ.

Клучни зборови: хипероксија, вентилатор-индуцирана повреда на белите дробови, цитокини, вентилација стратегии за заштита на белите дробови 